\title{
Dostęp do otworu szyjnego i jego otoczenia - analiza techniki operacyjnej w oparciu 0 symulacje na zwłokach
}

\section{Approach to the jugular foramen and related structures - an analysis of the surgical technique based on cadaver simulation}

Piotr Ładziński, Mariusz Maliszewski, Wojciech Kaspera, Krzysztof Majchrzak, Michał Tymowski

Katedra i Oddział Kliniczny Neurochirurgii w Sosnowcu, Śląski Uniwersytet Medyczny w Katowicach

Neurologia i Neurochirurgia Polska 2011; 45, 3: 260-274

\section{Streszczenie}

Celem pracy jest przedstawienie poszczególnych etapów dostępu do otworu szyjnego i jego otoczenia.

Przeprowadzono 11 symulacji dostępu na nieutrwalonych zwłokach ludzkich, u których nie podejrzewano procesów patologicznych w zakresie głowy i szyi. Kolejne fazy symulacji były dokumentowane fotograficznie oraz schematami. Punktem wyjścia dla omawianego dostępu jest resekcja części sutkowej i tylnych partii części skalistej kości skroniowej, jak również wyrostka i guzka szyjnego. Pozwala to na penetrację otworu szyjnego od tyłu. Poszerzanie dostępu umożliwia penetrację otworu szyjnego od góry i od przodu.

Dostęp do otworu szyjnego stanowi powtarzalną metodę penetracji tego otworu i jego otoczenia. Dostęp ten jest szczególnie przydatny w leczeniu operacyjnym guzów nowotworowych rozrastających się w piramidzie kości skroniowej, otoczeniu odcinka skalistego tętnicy szyjnej wewnętrznej, kącie mostowo-móżdżkowym, dole podskroniowym i pęczku naczyniowo-nerwowym szyi.

Słowa kluczowe: otwór szyjny, podstawa czaszki, ką mostowo-móżdżkowy, piramida kości skroniowej, mikrochirurgia.

\begin{abstract}
This study presents consecutive stages of the approach to the jugular foramen and related structures.

Eleven simulations of the approach were performed on nonfixed human cadavers without any known pathologies in the head and neck. The consecutive stages of the procedure were documented with photographs and schematic diagrams. The starting point for the discussed approach is removal of the mastoid and petrosal parts of the temporal bone, as well as the jugular process and the jugular tuberculum. It allows penetration of the jugular foramen from the back. Widening of the approach enables penetration of the jugular foramen from above and the front.

Approach to the jugular foramen is a reproducible technique, which provides surgical penetration of this foramen and related structures. This approach is particularly useful in the surgical treatment of tumours expanding in the petrous pyramid, surroundings of the petrosal part of the internal carotid artery, cerebellopontine angle, subtemporal fossa and nervousvascular bundle of the neck.
\end{abstract}

Key words: jugular foramen, skull base, cerebellopontine angle, petrous pyramid, microsurgery.

Adres do korespondencii: dr hab. n. med. Piotr Ładziński, Katedra i Oddział Kliniczny Neurochirurgii, Śląski Uniwersytet Medyczny w Katowicach, Wojewódzki Szpital Specjalistyczny nr 5 im. św. Barbary, Pl. Medyków 1, 41-200 Sosnowiec, tel. +4832 368 20 24, faks: +4832 3682550 , e-mail:sekr_nch@wss5.pl

Pracę otrzymano: 1.12.2010; przyięto do druku: 14.02.2011 


\section{Wstęp}

Złożoność budowy anatomicznej otoczenia otworu szyjnego jest wyznacznikiem trudności technicznych, jakich nastręczają działania chirurgiczne w jego okolicy. Istnieje znamienna zależność między stopniem tych trudności a rozmiarami poddawanych leczeniu guzów, wychodzących z otworu szyjnego. Zależność ta wynika $\mathrm{z}$ tego, że bez względu na kierunek, w którym rozprzestrzeniają się owe guzy, mogą one prowadzić do wystąpienia poważnych zaburzeń klinicznych. Dotyczy to zarówno kąta mostowo-móźdżkowego, ucha środkowego i wewnętrznego, nerwu twarzowego, tętnicy szyjnej wewnętrznej aż po zatokę jamistą, jak i pęczka naczyniowo-nerwowego szyi. Celem niniejszej pracy jest przedstawienie własnej interpretacji, ujętego w trzy zakresy, dostępu operacyjnego do otworu szyjnego i jego otoczenia.

\section{Materiał i metody}

W październiku 1997 r. przy Oddziale Klinicznym Neurochirurgii Śląskiego Uniwersytetu Medycznego została utworzona Pracownia Neuroanatomii Chirurgicznej. Pracownia ta powstała na bazie prosektorium Wojewódzkiego Szpitala Specjalistycznego nr $5 \mathrm{im}$. św. Barbary w Sosnowcu, w którym mieści się oddział. Przeznaczeniem pracowni jest symulowanie na zwłokach ludzkich różnych typów operacji neurochirurgicznych. Wyposażenie pracowni stanowi podstawowe instrumentarium neurochirurgiczne wykorzystywane w działaniach makro- i mikroskopowych, jak również ssak elektryczny, trepan elektryczny i wiertarka szybkoobrotowa. Jeden ze stołów prosektoryjnych został zmodyfikowany w celu umożliwienia mocowania do niego czaszkotrzymacza i stolika Mayo. Pracownia ma mikroskop operacyjny zamontowany na przewoźnym statywie, wyposażony w stereoskopowy okular, zmienny zakres powiększenia od 0,5 do 25 razy, źródło światła i sprzężoną z gniazdem do aparatu fotograficznego lampą błyskową. Do mikroskopu dostosowano cyfrowy aparat fotograficzny.

Do symulacji kwalifikowano zmarłych, u których były przeprowadzane sekcje lekarskie, a u których nie podejrzewano procesów patologicznych w zakresie głowy i szyi. Symulacje przeprowadzano we współpracy z patomorfologami i prosektorami. Współpraca z patomorfologami dotyczyła dostosowania symulacji do przebiegu sekcji lekarskiej. Przyjęto zasadę, że przeprowadzane symulacje nie naruszają w sposób widoczny zwłok w stopniu większym, niż to wynika z sekcji lekarskiej. Rzutowało to na sposoby przeprowadzania cięć skórnych, rozbieżne z założeniami chirurgicznymi, a zgodne $\mathrm{z}$ wymogami prosektorów.

Symulacje przeprowadzano w pierwszej dobie po zgonie na zwłokach nieutrwalonych, bez wypełnienia łoża naczyniowego środkami cieniującymi. Ograniczało to czytelność struktur anatomicznych, natomiast uzyskane warunki były zbliżone do panujących w polu operacyjnym.

Wykonano 11 symulacji dostępu do otworu szyjnego i jego otoczenia. Wykorzystano zwłoki osobników dorosłych obojga płci. Każdy etap symulacji dokumentowano fotograficznie. Do każdej z fotografii sporządzano schemat, udoskonalany przez plastyka.

\section{Wyniki}

\section{Przebieg symulacii dostępu do otworu szyjnego w zakresie pierwszym, umożliwiajqcym usunięcie tylnego ograniczenia tego otworu}

Pozycja na wznak z uniesieniem barku po stronie operacji o ok. $45^{\circ}$ i skręceniem głowy w kierunku przeciwnym do operacji o ok. $30^{\circ}$. Osoba operowana ustabilizowana na blacie operacyjnym w sposób umożliwiający rotację blatu na boki w czasie trwania operacji o ok. $30^{\circ}$ (ryc. 1.).

Cięcie skórne rozpoczyna się $2 \mathrm{~cm}$ powyżej małżowiny usznej i zatacza łuk przebiegający ok. $4 \mathrm{~cm}$ ku tyłowi od niej. Dalej kieruje się $2 \mathrm{~cm}$ ku tyłowi od wyrostka sutkowatego, a następnie krzyżuje mięsień mostkowo-

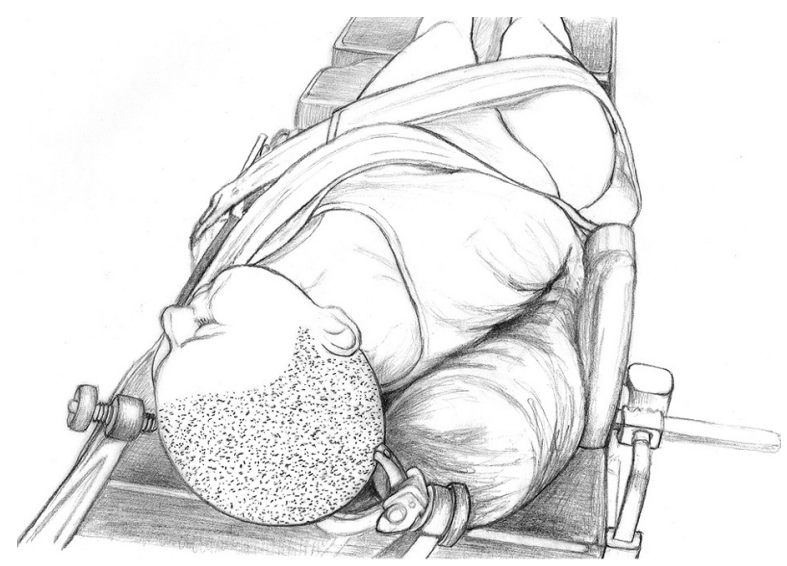

Ryc. 1. Pozycia na wznak ze skręcong gtowa, uniesieniem barku i ustabilizowaniem na blacie operacyinym

Fig. 1. Supine position with the head turned, elevation of the shoulder and stabilization on the operating table 


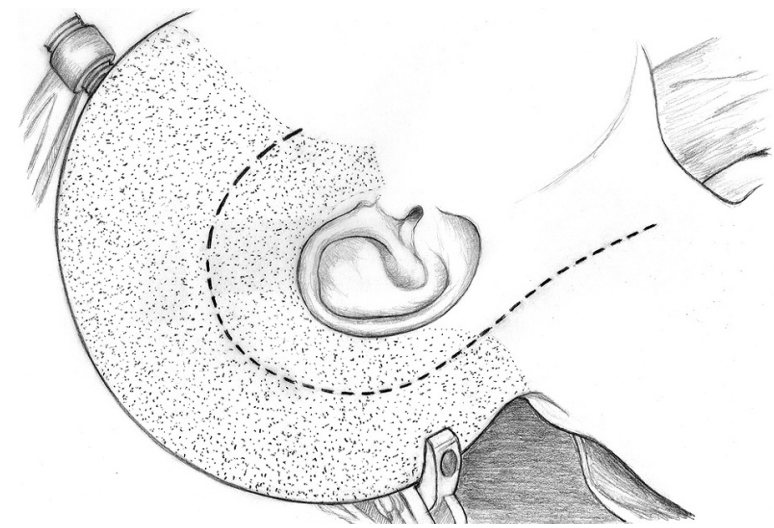

Ryc. 2. Cięcie skórne dla odsłonięcia dolnej części piramidy kości skroniowej i jei otoczenia. Zakres I - krótka linia przerywana, zakres II i III - długa linia przerywana

Fig. 2. Skin incision for exposing lower part of the petrous pyramid and its surrounding. Range I - short segments of dashed line, ranges II and III - long segments of the dashed line

-obojczykowo-sutkowy i kończy się przy krawędzi przedniej tego mięśnia w połowie jego długości (ryc. 2.). Cięcie jest prowadzone przez skórę, powięzie mięśni i okostną.

Płat skórno-powięziowo-okostnowy zostaje stopniowo odchylony do przodu i ku dołowi w taki sposób, by w szypule płata zawierała się zmobilizowana od góry, tyłu i dołu skóra przewodu słuchowego zewnętrznego (ryc. 3.). W czasie odchylania płata istotne jest uniknięcie uszkodzenia nerwu usznego wielkiego.

Mobilizacja mięśni dotyczy niektórych mięśni długich grzbietu, niektórych mięśni powierzchownych szyi i mięśnia skroniowego. Rozpoczyna się odcięciem bliższego przyczepu mięśnia mostkowo-obojczykowo-sutkowego. Zakres odchylenia tego mięśnia ku dołowi jest ograniczony przebiegiem nerwu dodatkowego. W dalszej kolejności zostają odcięte bliższe przyczepy mięśni płatowatego głowy, najdłuższego głowy i półkolcowego głowy. Mięśnie te zostają odchylone ku dołowi i ku tyłowi. Odchylenie dwóch ostatnich mięśni wymaga zamknięcia tętnicy potylicznej. Mięsień skroniowy zostaje przecięty wzdłuż linii cięcia skórnego na odcinku od tylnej krawędzi mięśnia do wysokości małżowiny usznej. Część mięśnia poniżej przecięcia zostaje odchylona na płat skórno-powięziowo-okostnowy (ryc. 4.).

Usunięcie mięśni dotyczy takich mięśni podpotylicznych, jak skośny głowy górny, prosty głowy tylny większy oraz prosty głowy boczny, jak również brzuśca tylnego mięśnia dwubrzuścowego (ryc. 4.).

Identyfikacja pęczka naczyniowo-nerwowego szyi obejmuje takie twory naczyniowe, jak żyła i tętnica szyjna wewnętrzna oraz tętnica szyjna zewnętrzna. W przypadku bogato unaczynionego, niepoddanego embolizacji guza celowe jest odszukanie i podwiązanie odgałęzień tylnych tętnicy szyjnej zewnętrznej, czyli tętnic gardłowej wstępującej, potylicznej i usznej tylnej. Wśród tworów nerwowych identyfikacji podlegają nerwy dodatkowy, błędny i podjęzykowy wraz z gałęzią górną pętli szyjnej oraz pień współczulny. Identyfikacja nerwu językowo-gardłowego w pierwszym zakresie dostępu bywa utrudniona (ryc. 5.).
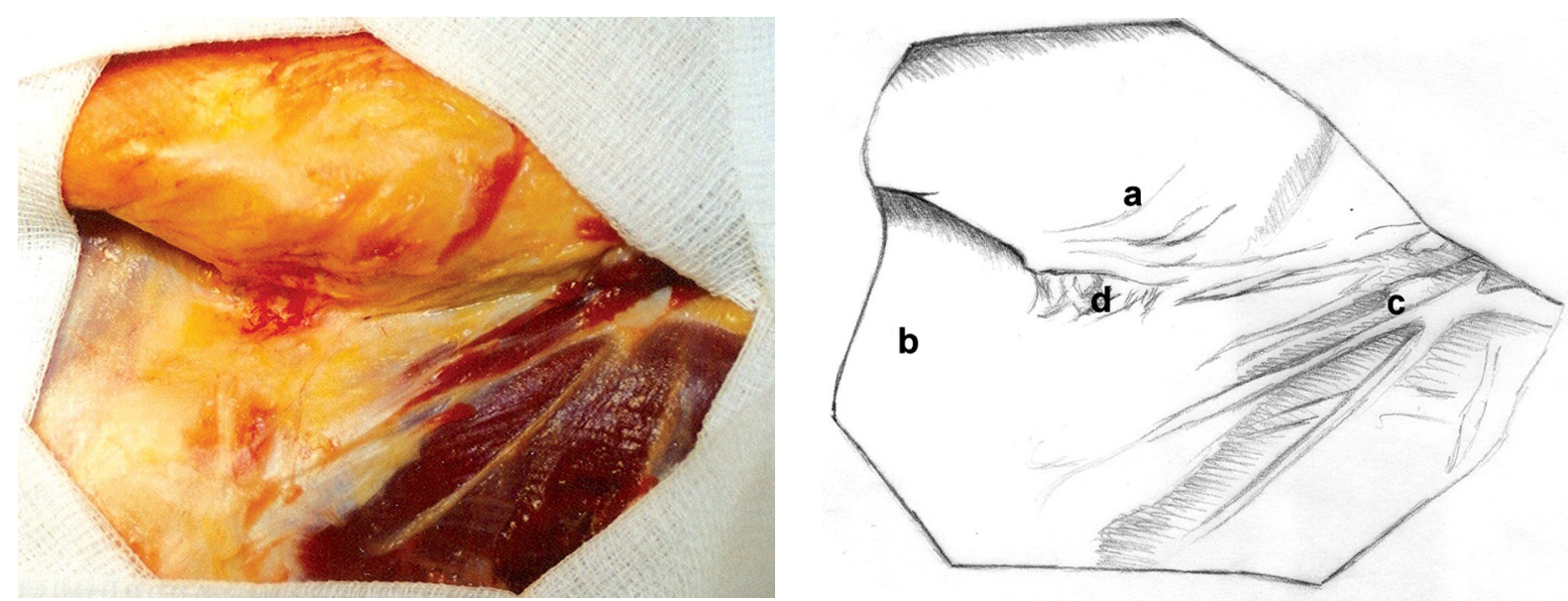

Ryc. 3. Odchylenie płata skórno-czepcowo-powięziowego; a - płat skórno-powięziowo-okostnowy, b - mięsień skroniowy, c - mięsień mostkowo-obojczykowo-sutkowy, $d$ - otoczenie przewodu słuchowego zewnętrznego

Fig. 3. Detachment of the dermal-fascial-periosteal flap; $a$ - dermal-fascial-periosteal flap, b-temporal muscle, c - sternocleidomastoid muscle, $d$ - surroundings of the external auditory meatus 

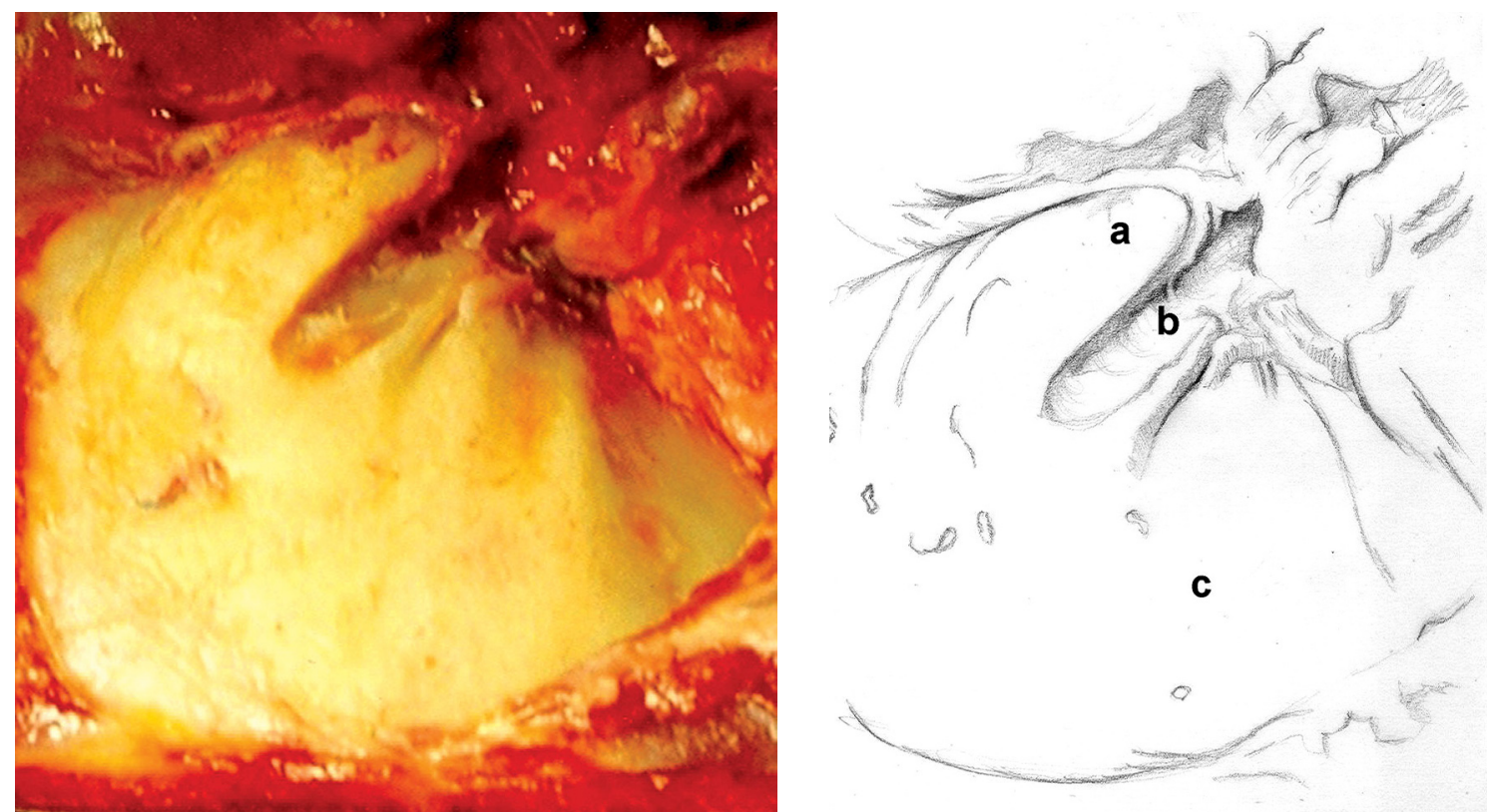

Ryc. 4. Mobilizacja i usunięcie mięśni warunkujące dostęp do otworu szyjnego; a - wyrostek sutkowaty, b - wcięcie sutkowe, c - łuska potyliczna

Fig. 4. Mobilisation and removal of the muscles required for approach to the jugular foramen; $a$ - mastoid process, $b$ - mastoid notch, c - occipital squama
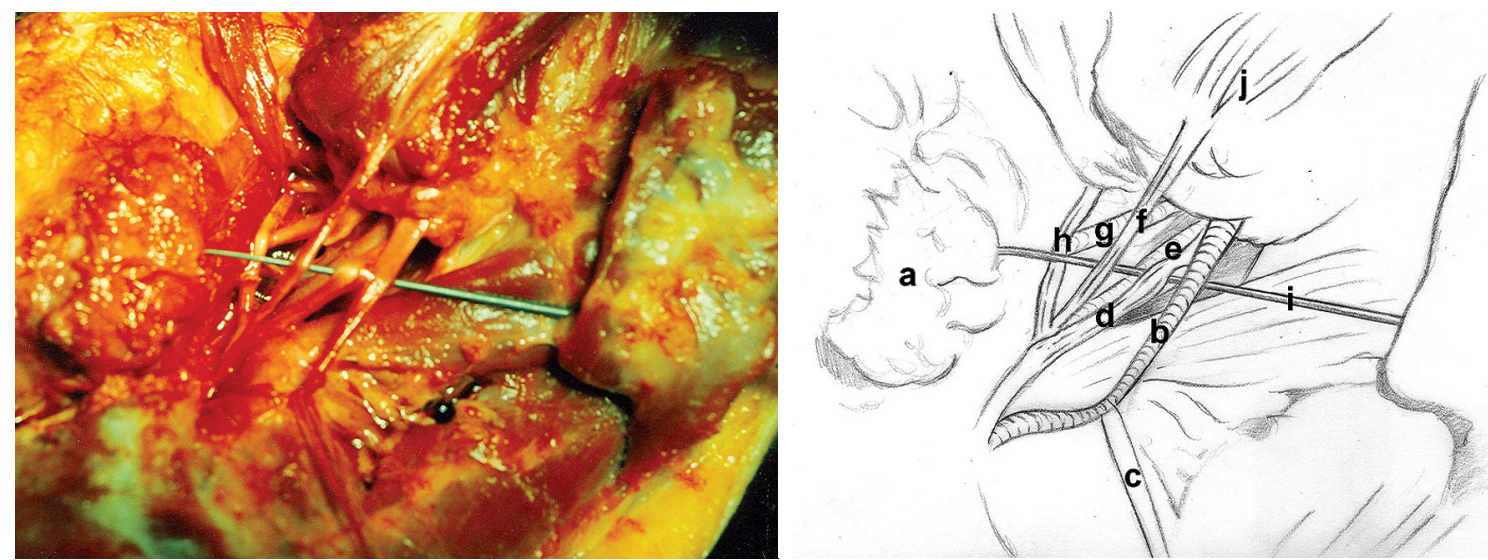

Ryc. 5. Identyfikacja pęczka naczyniowo-nerwowego szyi; a - ślinianka przyuszna, b - żyła szyjna wewnętrzna, c - szew cuglowy, d - nerw błędny, e - tętnica szyjna wewnętrzna, $\mathrm{f}$ - nerw dodatkowy, g - tętnica szyjna zewnętrzna, $\mathrm{h}$ - nerw podiezzykowy, i - haczyk, i - odchylony mięsień mostkowo-obojczykowo-sutkowy

Fig. 5. Identification of the nervous-vascular bundle of the neck; $a$ - parotid gland, $b$ - internal jugular vein, $c$ - reins, $d$-vagus nerve, $e-$ internal carotid artery, $f$ - accessory nerve, $g$ - external carotid artery, $h$ - hypoglossal nerve, $i$ - small hook, $i$ - sternocleidomastoid muscle detached

Identyfikacja odcinka podpotylicznego $\left(\mathrm{V}_{3}\right)$ tętnicy kręgowej dotyczy jedynie jego części powyżej otworu wyrostka poprzecznego kręgu szczytowego. Nie jest konieczne usuwanie splotu żylnego otaczającego tętnicę, natomiast pomocne w usunięciu guza może okazać się zamknięcie rozbudowanych gałęzi mięśniowych, które mogą uczestniczyć w jego unaczynieniu (ryc. 6.).

Kraniektomia podpotyliczna rozpoczyna się nawierceniem otworu trepanacyjnego w odległości ok. $2 \mathrm{~cm}$ od szwu potyliczno-sutkowego, przyśrodkowo od szwu i w połowie jego długości. Kraniektomia obejmuje boczno-dolną część łuski kości potylicznej oraz dół kłykciowy. Górno-boczna część kraniektomii odsłania pogranicze zatok porzecznej, esowatej i skalistej górnej (ryc. 6.).

Resekcja części sutkowej i tylnych partii części skalistej kości skroniowej rozpoczyna się od wytworzenia bruzdy w blaszce zewnętrznej kości, która biegnie wokół tylnego ograniczenia otworu słuchowego zewnętrznego, wzdłuż szypuły płata skórno-powięziowo-okostnowego, powyżej i poniżej otworu, a następnie na 

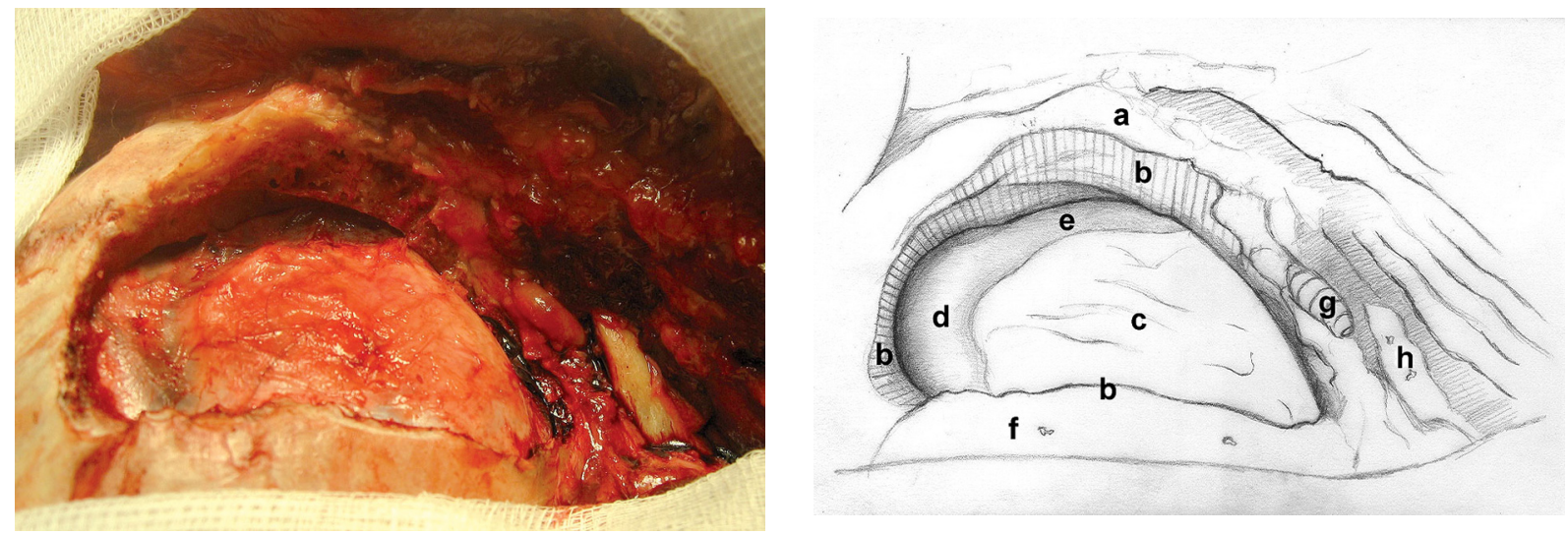

Ryc. 6. Kraniektomia podpotyliczna; $a$ - wyrostek sutkowaty, b - granice kraniektomii, c - opona twarda w okolicy podpotylicznei, d - zatoka poprzeczna, e - zatoka esowata, $\mathrm{f}$ - łuska potyliczna, $\mathrm{g}$ - podpotyliczny odcinek tętnicy kręgowej, $\mathrm{h}$ - tylny łuk kręgu szzzytowego

Fig. 6. Suboccipital craniectomy; a - mastoid process, b-margins of craniectomy, $c$ - suboccipital dura, $d$ - transverse sinus, e - sigmoid sinus, $f$ - occipital squama, $g$ - suboccipital part of the vertebral artery, $h$ - posterior arch of the atlas
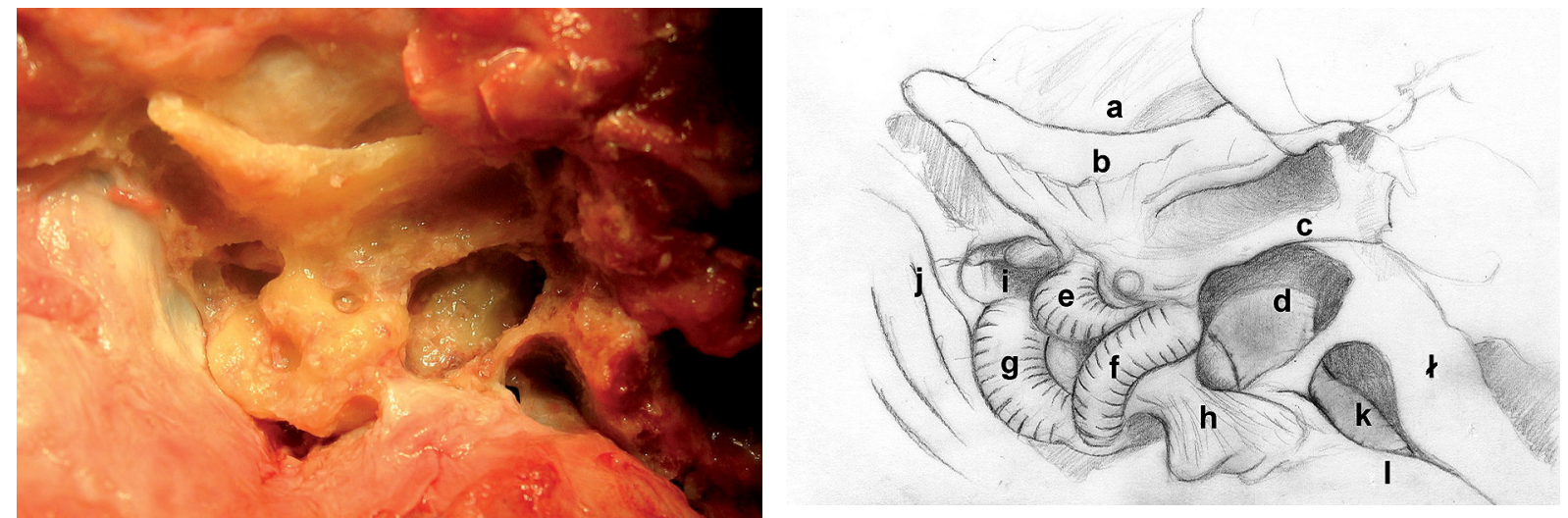

Ryc. 7. Usunięcie komórek powietrznych części sutkowej i tylnych partii części skalistej kości skroniowei; a - chrzęstne otoczenie przewodu słuchowego zewnętrznego, $b$ - kostne otoczenie przewodu słuchowego zewnętrznego, $c$ - kanał nerwu twarzowego w odcinku sutkowym, $d$ - kostne otoczenie opuszki żyły szyjnej, e - kanał pótkolisty boczny, $\mathrm{f}$ - kanał półkolisty tylny, $\mathrm{g}$ - kanał półkolisty górny, $\mathrm{h}$ - woreczek śródchłonki, i - wejście do jamy bębenkowei (widoczne kowadełko), $\mathrm{i}$ - opona twarda w okolicy skroniowej, k - zatoka esowata, I - opona twarda w okolicy podpotylicznej, † - granica kraniektomii podpotylicznej

Fig. 7. Removal of the pneumatic cells of mastoid and petrosal parts of the temporal bone; $a$ - cartilaginous surroundings of the external auditory meatus, $b$ - bony surroundings of the external auditory meatus, $c$ - mastoid part of the facial canal, $d$ - bony surroundings of the jugular bulb, $e$ - lateral semicircular canal, $f$ - posterior semicircular canal, $g$ - superior semicircular canal, $h$ - endolymphatic sac, $i$ - aditus ad antrum (incus visible), $i$ - temporal dura, $k$ - sigmoid sinus, l - suboccipital dura, $t$ - margins of suboccipital craniectomy

przedłużeniu osi zatoki poprzecznej oraz wokół wyrostka sutkowatego. Bruzda dochodzi do granic kraniektomii podpotylicznej w jej najwyższej i najniższej części. W zakresie wyznaczonym bruzdą zostaje usunięta blaszka zewnętrzna kości. Kolejną czynnością jest usunięcie komórek powietrznych części sutkowej i tylnych partii części skalistej kości skroniowej, co wiąże się ze zniesieniem jamy sutkowej. Zostają uwidocznione kostne ograniczenia kanałów półkolistych, kanału nerwu twarzowego w odcinku sutkowym, opuszki żyły szyjnej oraz wejścia do jamy bębenkowej (ryc. 7.).

\section{Zamknięcie zatoki esowatej i żyły szyjnej wewnętrz-} nej przeprowadza się, gdy usuwany guz wrasta do opuszki żyły szyjnej i związanych z nią dróg krążenia żylnego. Żyła szyjna wewnętrzna zostaje podwiązana, natomiast zatoka esowata może być podwiązana, po przecięciu opony twardej w jej otoczeniu, lub być linijnie nacięta i wypełniona surgicelem.

Penetracja przestrzeni wewnątrztwardówkowej jest podyktowana wnikaniem guza do tej przestrzeni. Linię cięcia opony twardej prowadzi się wzdłuż tylnego ograniczenia zatoki esowatej. W części górnej cięcie zakręca 

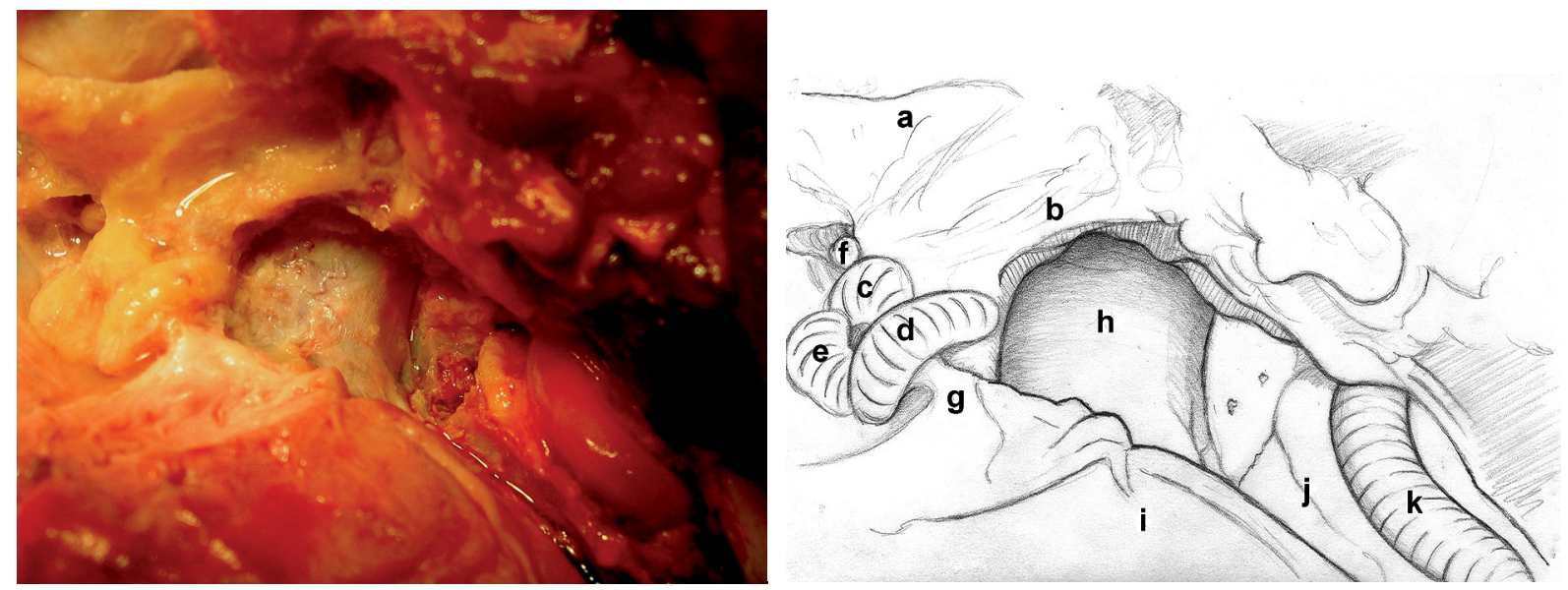

Ryc. 8. Usunięcie tylnego ograniczenia otworu szyinego; a - przewód słuchowy zewnętrzny, b - kanał nerwu twarzowego w odcinku sutkowym, c - kanał półkolisty boczny, $d$ - kanał półkolisty tylny, e - kanał półkolisty górny, $f$ - wejście do jamy bębenkowej (widoczne kowadełko), g - woreczek śródchłonki, $h$ - tylna część opuszki żyły szyinej, i - opona twarda w okolicy podpotylicznej, i - granica kraniektomii podpotylicznej, k - podpotyliczny odcinek tętnicy kręgowej

Fig. 8. Removal of the posterior surroundings of the jugular foramen; $a$ - external auditory meatus, b- mastoid part of the facial canal, $c$ - lateral semicircular canal, $d$ - posterior semicircular canal, $e$ - superior semicircular canal, $f$ - aditus ad antrum (incus visible), $g$ - endolymphatic sac, $h$ - posterior part of the jugular bulb, $i$ - suboccipital dura, $i$ - margins of suboccipital craniectomy, $k$ - suboccipital part of the vertebral artery

wzdłuż zatoki poprzecznej, a w części dolnej w kierunku otworu potylicznego wielkiego. Zsunięcie półkuli móżdżku daje wgląd do wszystkich pięter kąta mostowo-móżdżkowego.

Usunięcie tylnego ograniczenia otworu szyjnego obejmuje takie fragmenty kości potylicznej, jak tylno-boczna część kłykcia potylicznego, guzek szyjny i wyrostek szyjny. Usuwanie kłykcia potylicznego wymusza zamknięcie żyły wypustowej kłykciowej tylnej (ryc. 8.). Uzyskanie wglądu do wnętrza otworu szyjnego wymaga wycięcia tylnej ściany zatoki esowatej ponizej od miejsca jej zamknięcia do granicy z opuszką żyły szyjnej.

\section{Przebieg symulacii dostępu do otworu szyjnego w zakresie drugim, umożliwiającym usunięcie górnego ograniczenia tego otworu}

Przedłużenie cięcia skórnego obejmuje odcinek, który rozpoczyna się $4 \mathrm{~cm}$ powyżej łuku jarzmowego, w połowie jego długości i przechodzi w już wykonane cięcie (ryc. 2.).

Amputacja przewodu słuchowego zewnętrznego rozpoczyna się, przy podążaniu od strony szypuły płata skórno-czepcowo-okostnowego, przecięciem przewodu ze strony tylnej, górnej i dolnej, na wysokości cieśni przewodu, czyli na pograniczu części chrzęstnej i kostnej. Umożliwia to mobilizację, a następnie przecięcie przewodu od strony przedniej. Kolejną czynnością jest odwarstwienie skóry od chrząstki w odciętej, bliższej części prze- wodu w stopniu pozwalającym na wynicowanie jej na zewnątrz (ryc. 9.). Skóra zostaje zeszyta od strony małżowiny usznej i odprowadzona w swoje anatomiczne położenie w chrzęstnej części przewodu. Ten etap amputacji przewodu słuchowego zewnętrznego kończy uformowanie uszypułowanego płata okostnowego o wymiarach $2 \times 2 \mathrm{~cm}$ $z$ istniejącego już płata skórno-powięziowo-okostnowego i obszycie nim chrzęstnego otoczenia kikuta przewodu.

Identyfikacja nerwu twarzowego po wyjściu z otworu rylcowo-sutkowego następuje w połowie długości między dolnym ograniczeniem przewodu słuchowego zewnętrznego a szczytem wyrostka sutkowatego (ryc. 10.).

Usunięcie skóry części kostnej przewodu słuchowego zewnętrznego i błony bębenkowej to amputacyjne czynności, które powinny być jednak przeprowadzone w sposób planowy. Można je ująć w siedem etapów. Etap pierwszy to odwarstwienie skóry przewodu od kanału kostnego do miejsca przebiegu pierścienia włóknisto-chrzęstnego, otaczającego błonę bębenkową. Etap drugi to odwarstwienie części tylnej z uwidocznieniem jamy bębenkowej. Etap trzeci to przecięcie struny bębenkowej wewnątrz jamy bębenkowej. Etap czwarty to przerwanie połączenia stawowego między kowadełkiem a strzemiączkiem. Etap piąty to przecięcie szyjki młoteczka. Etap szósty to przecięcie ścięgna mięśnia napinacza błony bębenkowej. Etap siódmy to usunięcie w jednym fragmencie skóry części kostnej przewodu słuchowego zewnętrznego, błony bębenkowej oraz rękojeści młoteczka.

Mobilizacja części sutkowej nerwu twarzowego odbywa się na dwóch etapach. 

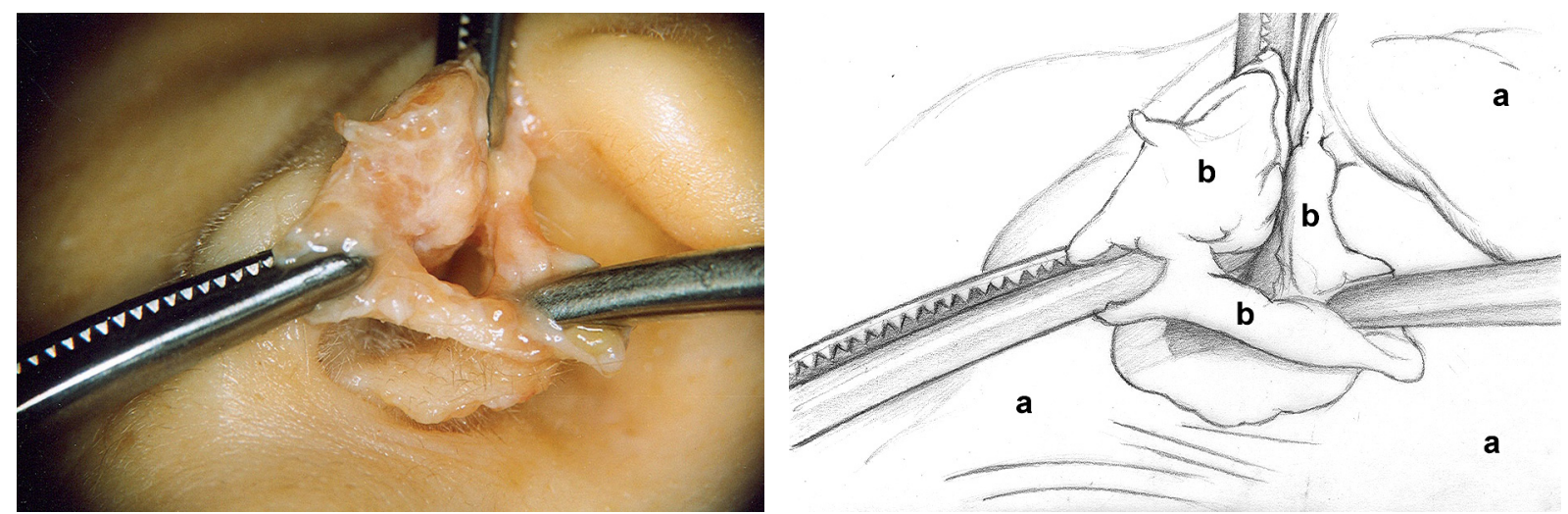

Ryc. 9. Wynicowanie skóry przewodu stuchowego zewnętrznego; a - matzowina uszna, b - wynicowana skóra czę́ci chrzęstnej przewodu stuchowego zewnętrznego Fig. 9. Eversion of the skin external auditory meatus; $a$ - auricle, $b$ - everted skin of the cartilaginous part of the external auditory meatus
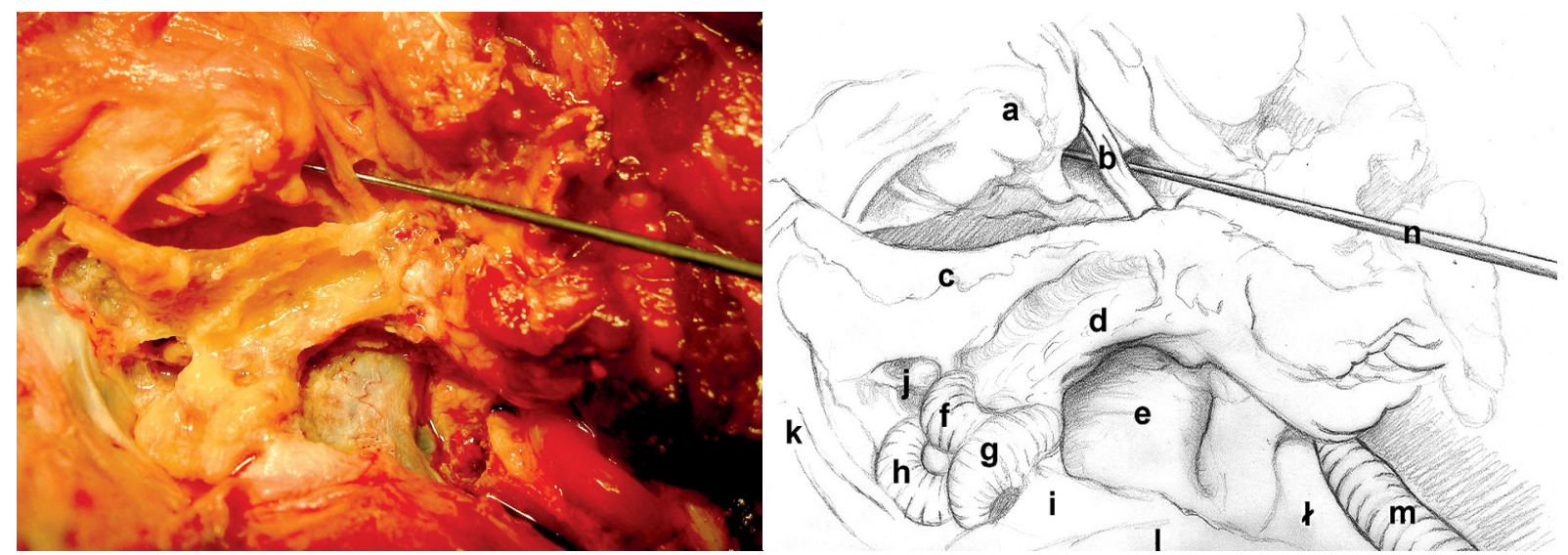

Ryc. 10. Identyfikacja nerwu twarzowego przy otworze rylcowo-sutkowym; a - ślinianka przyuszna, b- nerw twarzowy przy otworze rylcowo-sutkowym, c - przewód słuchowy zewnętrzny, d - kanał nerwu twarzowego w odcinku sutkowym, e - tylna część opuszki żyły szyjnej, $f$ - kanał pótkolisty boczny, $g$ - kanał półkolisty tylny, h - kanał półkolisty górny, i - woreczek śŕ́dchłonki, i - wejście do jamy bębenkowej (widoczne kowadełko), k - opona twarda w okolicy skroniowej, I - opona twarda w okolicy podpotylicznej, $\uparrow$ - granica kraniektomii podpotylicznej, m - podpotyliczny odcinek tętnicy kręgowej, $\mathrm{n}$ - dysektor

Fig. 10. Identification of the facial nerve at the stylomastoid foramen; a - parotid gland, b - facial nerve at the stylomastoid foramen, c - external auditory meatus, $d$ - mastoid part of the facial canal, e - posterior part of the jugular bulb, $f$ - lateral semicircular canal, $g$ - posterior semicircular canal, $h$ - superior semicircular canal, $i$ - endolymphatic sac, $i$ - aditus ad antrum (incus visible), $k$ - temporal dura, $I$ - suboccipital dura, $t$ - margins of suboccipital craniectomy, $m$ - suboccipital part of the vertebral artery, $n$ - dissector

Etap pierwszy to usunięcie górno-tylnej ściany części kostnej przewodu słuchowego zewnętrznego. Następuje też usunięcie głowy młoteczka. Etap drugi to mobilizacja części sutkowej nerwu twarzowego od otworu rylcowo-sutkowego do poziomu połączenia jamy bębenkowej z jamą sutkową, połączoną z odcięciem od pnia nerwu struny bębenkowej, nerwu usznego tylnego oraz gałęzi dwubrzuścowej (ryc. 11.).

Mobilizacja cześci bębenkowej nerwu twarzowego kończy się na wysokości zwoju kolanka i połączona jest $\mathrm{z}$ odcięciem od pnia nerwu twarzowego nerwu strzemiączkowego. Czynność tę poprzedza usunięcie kowadełka bez wyluksowania strzemiączka z okienka owalnego.
Repozycja przednia nerwu twarzowego rozpoczyna się wyżłobieniem w przednim ograniczeniu jamy bębenkowej bruzdy, do której ma zostać przemieszczony nerw. Następnie zostaje zmobilizowany splot nerwu twarzowego w miąższu ślinianki przyusznej. Repozycja polega na przemieszczeniu zmobilizowanego nerwu w jego nowe położenie do przodu od jamy bębenkowej (ryc. 12.).

Identyfikacja początkowej części odcinka skalistego poziomego tętnicy szyjnej wewnętrznej polega na usunięciu dolnego ograniczenia ujścia bębenkowego trąbki słuchowej. Stopniowo ukazuje się ściana górna i tylna tętnicy (ryc. 12.). 

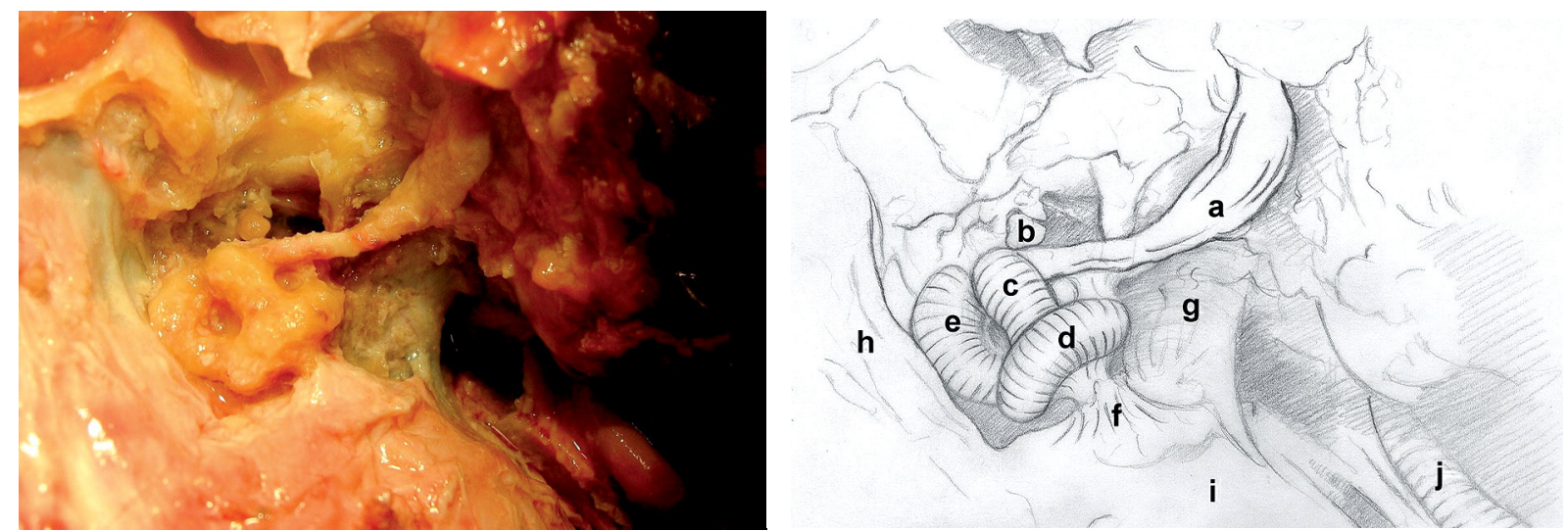

Ryc. 11. Zmobilizowanie części sutkowej nerwu twarzowego po usunięciu tylnej ściany przewodu słuchowego zewnętrznego; a - część sutkowa nerwu twarzowego, b-kowadełko, c - kanał półkolisty boczny, d - kanał półkolisty tylny, e - kanał półkolisty górny, $\mathrm{f}$ - woreczek śródchłonki, g - tylna część opuszki żyły szyjnej, h - opona twarda w okolicy skroniowej, i - opona twarda w okolicy podpotylizznej, i - podpotyliczny odcinek tętnicy kręgowej

Fig. 11. Mobilisation of the mastoid part of the facial nerve after removal of the posterior wall of the external auditory meatus; a - mastoid part of the facial nerve, $b$ - incus, c - lateral semicircular canal, $d$ - posterior semicircular canal, e - superior semicircular canal, $f$ - endolymphatic sac, $g$ - posterior part of jugular bulb, $h$ - temporal dura, $i$ - suboccipital dura, $i$ - suboccipital part of the vertebral artery
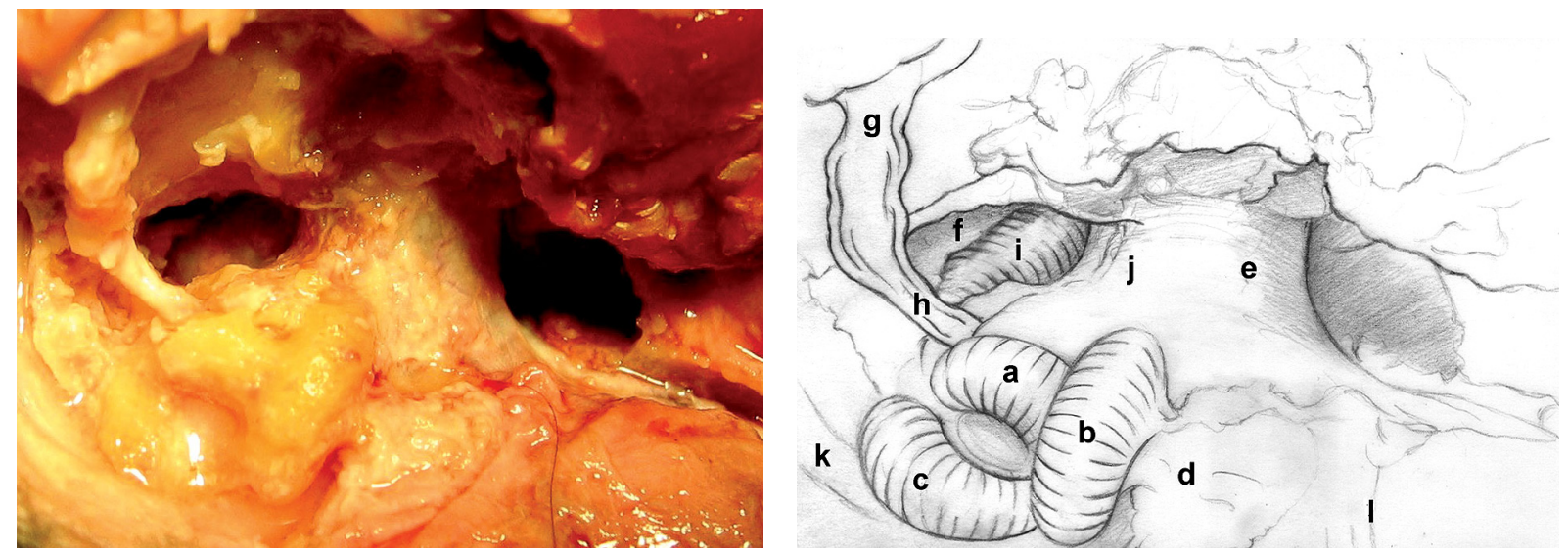

Ryc. 12. Usunięcie górnego ograniczenia otworu szyjnego po repozycii przedniej nerwu twarzowego; a - kanał półkolisty boczny, b - kanał półkolisty tylny, c - kanał półkolisty górny, $\mathrm{d}$ - woreczek śródchłonki, e - tylna cześśc opuszki żłły szyjnej, $\mathrm{f}$ - ujście bębenkowe trąbki słuchowej, $\mathrm{g}$ - cześś sutkowa nerwu twarzowego po repozycii przedniej, $\mathrm{h}$ - część bębenkowa nerwu twarzowego po repozycii przedniej, $\mathrm{i}$ - odcinek skalisty tętnicy szyjnej wewnętrznej, $\mathrm{i}$ - górna cześśc opuszki żyły szyjnej, k - opona twarda w okolicy skroniowej, I - opona twarda w okolicy podpotylicznej

Fig. 12. Removal of the upper surroundings of the jugular foramen after anterior repositioning of the facial nerve; $a$ - lateral semicircular canal, $b$ - posterior semicircular canal, c - superior semicircular canal, $d$ - endolymphatic sac, e - posterior part of the jugular bulb, $f$-tympanic opening of the auditory fube, $g$ - mastoid part of the facial nerve after anterior repositioning, $h$ - tympanic part of the facial nerve after anterior repositioning, $i$ - petrosal segment of the internal carotid artery, $i$ - upper part of the jugular bulb, $k$ - temporal dura, I- suboccipital dura

Usunięcie górnego ograniczenia otworu szyjnego obejmuje fragment części skalistej kości skroniowej zawarty między ścianą dolną jamy bębenkowej a otworem szyjnym. Fragment ten jest określany jako hypotympanum (ryc. 12.).

\section{Przebieg symulacji dostępu do otworu szyjnego w zakresie trzecim, umożliwiającym usunięcie przedniego i bocznego ograniczenia tego otworu}

Mobilizacja ślinianki przyusznej dokonywana jest przez jej zewnątrzokostnowe odwarstwienie od części bębenkowej kości skroniowej. Gruczoł zostaje przemieszczony ku przodowi, co pozwala na uwidocznienie do tyłu od niego brzegu tylnego gałęzi żuchwy oraz wyrostka rylcowatego wraz z przyczepiającymi się do niego mięśniami i ścięgnami.

Usunięcie wyrostka rylcowatego wymaga jego złamania u nasady i odcięcia od mięśni rylcowo-gnykowego, rylcowo-gardłowego i rylcowo-językowego oraz więzadeł rylcowo-gnykowego i rylcowo-żuchwowego. Ukazuje się końcowa część odcinka szyjnego tętnicy szyjnej wewnętrznej oraz nerw językowo-gardłowy (ryc. 13.). 

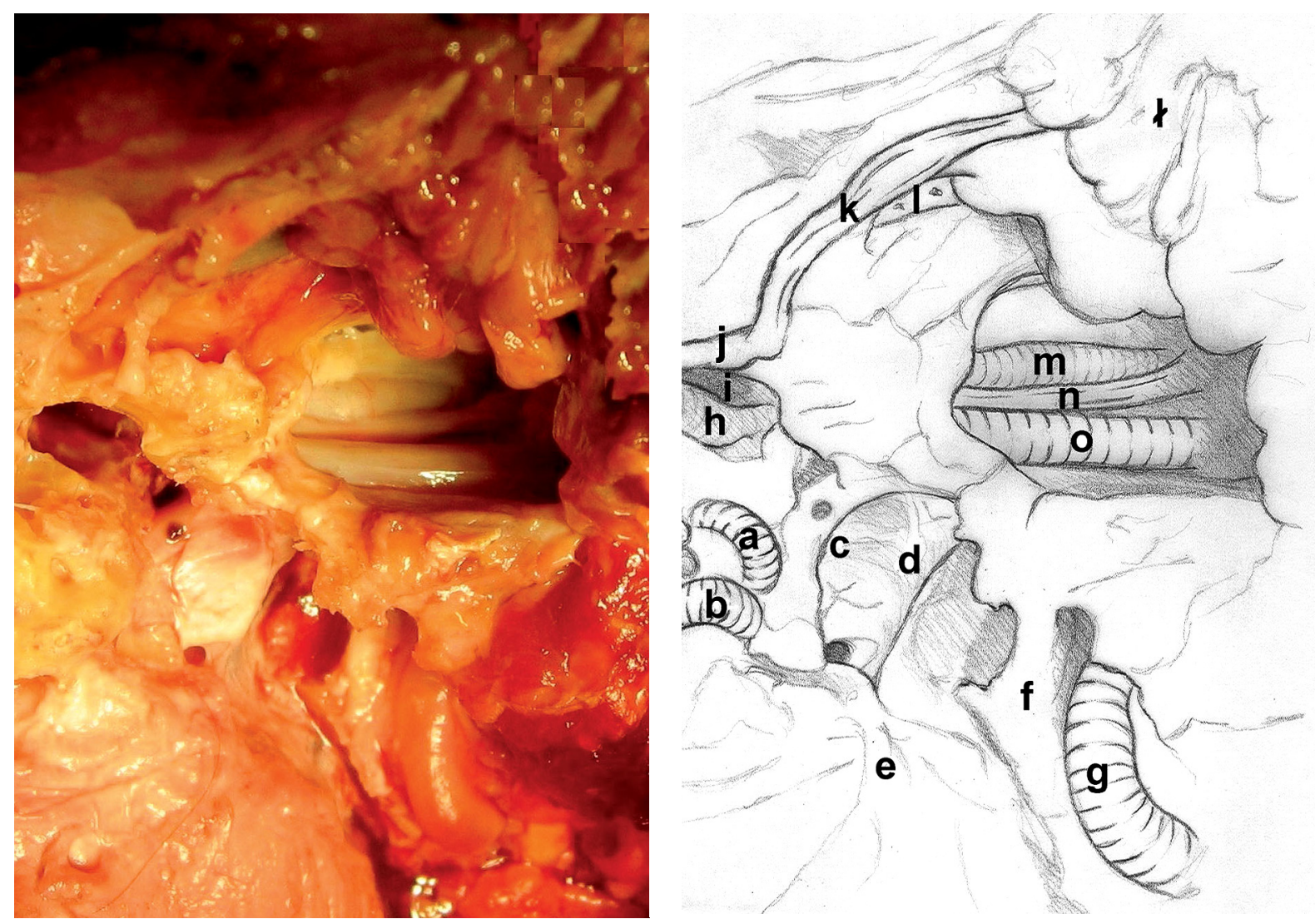

Ryc. 13. Usunięcie wyrostka rylcowatego; a - kanał pótkolisty boczny, b - kanał półkolisty tylny, c - górna czesść opuszki żyły szyinej, d - tylna część opuszki żyły szyjnej, e - opona twarda w okolicy podpotylicznej, $f$ - granica kraniektomii podpotylicznej, $g$ - podpotyliczny odcinek tętnicy kręgowej, $\mathrm{h}$ - odcinek skalisty tętnicy szyjnej wewnętrznej, i - vjście bębenkowe trąbki słuchowej, i - częśś bębenkowa nerwu twarzowego po repozycii przedniej, k - częśś sutkowa nerwu twarzowego po repozycii przedniej, I - gałąż żuchwy, $\nmid$ - ślinianka przyuszna, $\mathrm{m}$ - koniec odcinka szyjnego tętnicy szyjnej wewnętrznej, $\mathrm{n}$ - nerw językowo-gardłowy, 0 - żyła szyjna wewnętrzna

Fig. 13. Removal of the styloid process; a - lateral semicircular canal, b- posterior semicircular canal, c - upper part of the jugular bulb, $d$ - posterior part of the jugular bulb, $e$ - suboccipital dura, $f$ - margins of suboccipital craniectomy, $g$ - suboccipital part of the vertebral artery, $h$ - petrosal segment of the internal carotid artery, $i$ - tympanic opening of the auditory tube, $i$ - tympanic part of the facial nerve affer anterior repositioning, $k$ - mastoid part of the facial nerve after anterior repositioning, I - mandibular ramus, $t$ - parotid gland, $m$ - the end of the cervical part of the internal carotid artery, $n$ - glossopharyngeal nerve, 0 - jugular vein

Subluksacja żuchwy jest osiągana przez założenie rozwórki, której jedno ramię opiera się na tylnej krawędzi cięcia skórnego, a drugie na brzegu tylnym ramienia żuchwy. Rozwórka nie może uciskać ślinianki przyusznej ani przemieszczonego nerwu twarzowego.

Identyfikacja odcinka skalistego wstępującego i krzywizny tylnej tętnicy szyjnej wewnętrznej wymaga resekcji części bębenkowej kości skroniowej oraz dolno-bocznych partii części skalistej kości skroniowej. Istotne jest zidentyfikowanie i skoagulowanie gałęzi szyjno-bębenkowej tętnicy szyjnej wewnętrznej, tak by uniknąć jej wyrwania ze ściany tej tętnicy (ryc. 14.).

Usunięcie przedniego ograniczenia otworu szyjnego obejmuje fragment części skalistej kości skroniowej zawarty między kanałem tętnicy szyjnej wewnętrznej a otworem szyjnym (ryc. 14.).
Zamknięcie w pierwszej kolejności obejmuje odtworzenie ciągłości opony twardej. Dotyczy to zeszycia nacięć, jeżeli były dokonywane, oraz oblania klejem tkankowym miejsc przechodzenia przez oponę nerwów językowo-gardłowego, błędnego oraz dodatkowego. W zależności od dokonanego zakresu otwarcia, zamknięcia wymaga miejsce połączenia jamy sutkowej z jamą bębenkową albo ujście bębenkowe trąbki słuchowej. W obydwu przypadkach usunięcia wymaga błona śluzowa. Otwór jest wypełniany fragmentem mięśnia i woskiem. W przypadku trąbki słuchowej stopniowe usuwanie otoczenia kostnego wokół jej ujścia bębenkowego pozwala na zbliżenie się do jej cieśni, gdzie dokonanie zamknięcia jest łatwiejsze. Przestrzeń po usuniętej części skalistej kości skroniowej zostaje wypełniona autogenną tkanką tłuszczową. Mięśnie mostkowo-oboj- 

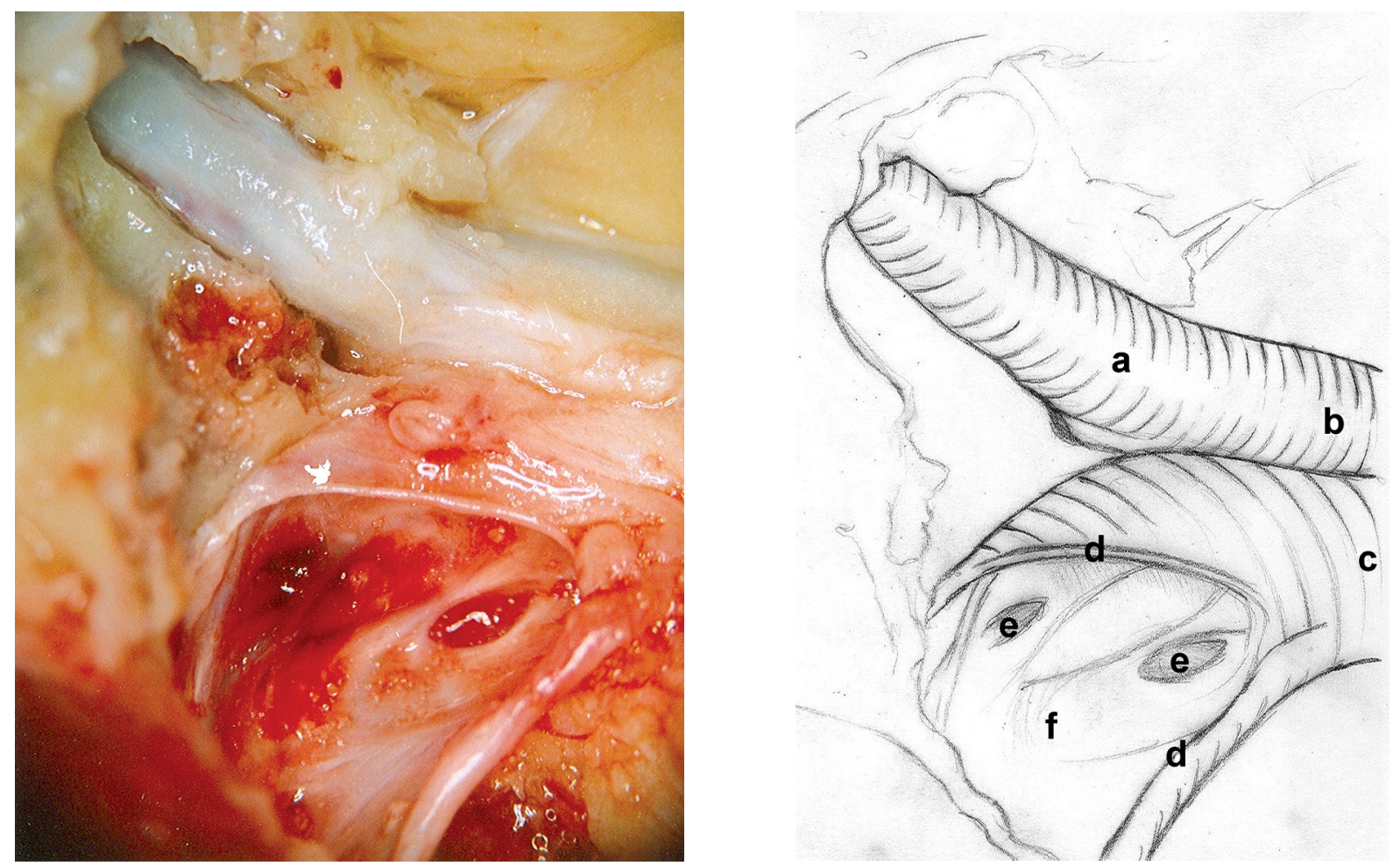

Ryc. 14. Pełne wyeksponowanie otworu szyjnego; a - odcinek skalisty tętnicy szyjnej wewnętrznej, b - koniec odcinka szyjnego tętnicy szyjnej wewnętrznej, c - żyła szyjna wewnętrzna, $\mathrm{d}$ - granica wycięcia ściany bocznej opuszki żyły szyjnej, e - vjścia zatoki skalistej dolnej, $\mathrm{f}$ - przyśrodkowa ściana opuszki żyły szyjnej przesłaniająca przedział nerwowy otworu szyjnego

Fig. 14. Full display of the jugular foramen; $a$ - petrosal segment of the internal carotid artery, $b$ - the end of the cervical part of the internal carotid artery, $c$ - jugular vein, $d$ - margins of the excision of the lateral wall of the jugular bulb, e- ostia of the inferior petrosal sinus, $f$ - medial wall of the jugular bulb concealing the pars nervosa of the jugular foramen

czykowo-sutkowy, najdłuższy głowy, płatowaty głowy i półkolcowy głowy zostają doszyte częściowo do zreponowanej ku dołowi tylno-dolnej części mięśnia skroniowego, a częściowo do otworków w krawędzi kraniektomii podpotylicznej. Płat skórno-powięziowo-okostnowy zostaje przywrócony. Szwy podskórne zostają założone nie tylko wzdłuż linii cięcia, ale też pod płatem, tak by zlikwidować wolną przestrzeń. Loża zostaje zdrenowana. Zamknięcie kończą szwy skórne.

\section{Omówienie}

Sposoby i możliwości chirurgicznej penetracji otworu szyjnego i jego otoczenia pozostają w łatwej do prześledzenia relacji $z$ anatomicznymi uwarunkowaniami tego otworu. Otwór szyjny jest położony głęboko w podstawie czaszki, między kością skroniową a potyliczną [1]. Kształt otworu oscyluje między trójkątnym a owalnym, przy czym prawy jest na ogół większy od lewego, co idzie w parze z większą średnicą zatoki esowatej i żyły szyjnej wewnętrznej [2-4]. Długa oś otworu układa się od tyłu i boku do przodu i w kierunku przyśrodkowym [3]. W opinii autorów niniejszej pracy odrębność topograficzna omawianego otworu, przy jego ocenie od strony światła jamy czaszki i od strony podstawy czaszki, jest tak znaczna, że otwór szyjny powinien być nazywany raczej kanałem szyjnym. Otwór szyjny zawiera w sobie przestrzenny twór anatomiczny, jakim jest dół szyjny otaczający opuszkę żyły szyjnej. Arnautović i AlMefty [5] opowiadają się za używaniem pojęcia „otwór szyjny" tylko w odniesieniu do otworu łączącego tylny dół czaszki z dołem szyjnym.

Od góry otoczenie otworu stanowi jama bębenkowa, sporadycznie - przyległy do niej odcinek przewodu słuchowego zewnętrznego, dość rzadko - labirynt i przyległa do niego część przewodu słuchowego wewnętrznego $[4,6,7]$. Do przodu od otworu szyjnego leży odcinek skalisty wstępujący tętnicy szyjnej wew- 
nętrznej, a przyśrodkowo od niego kłykieć potyliczny i zawarty w nim kanał nerwu podjęzykowego $[3,6,8]$. Od tyłu otwór jest ograniczony przez wyrostek szyjny kości potylicznej, będący przyczepem mięśnia prostego głowy bocznego. Boczne otoczenie otworu stanowi wyrostek sutkowy wraz z kanałem nerwu twarzowego. Patrząc do boku, można spotkać się z konfiguracją, w której kanał nerwu twarzowego nakłada się na środkową część opuszki żyły szyjnej lub na jej $1 / 3$ przednią, względnie $1 / 3$ tylną [7]. Może to mieć istotny wpływ na zakres resekcji wyrostka sutkowatego i konieczność mobilizacji nerwu twarzowego w dostępie operacyjnym do otworu szyjnego. Uzupełnienie bocznego otoczenia, bardziej z przodu, stanowi nasada wyrostka rylcowatego $[3,4]$.

Do struktur anatomicznych przechodzących przez otwór szyjny należą: zatoka esowata przechodząca w opuszkę żyły szyjnej i dalej w żyłę szyjną wewnętrzną, gałęzie oponowe tętnicy gardłowej wstępującej i tętnicy potylicznej, nerwy: językowo-gardłowy, błędny i dodatkowy, oraz wodociąg ślimaka $[2,3,9]$. Nerwy językowo-gardłowy i błędny mają zwoje górne i dolne, które są zlokalizowane w otworze lub jego bezpośrednim otoczeniu. Od zwoju dolnego nerwu językowo-gardłowego odchodzi nerw bębenkowy (nerw Jacobsona), który przez splot bębenkowy i nerw skalisty mniejszy przekazuje przywspółczulne unerwienie ślinianki przyusznej [10]. Od zwoju górnego nerwu błędnego odchodzi gałąź uszna (nerw Arnolda), jedyna gałąź skórna nerwu błędnego, która częściowo zespala się z nerwem twarzowym [3]. Do gałęzi usznej dochodzi gałąź, która łączy się ze zwojem dolnym nerwu językowo-gardłowego.

Część skalista kości skroniowej i część boczna kości potylicznej tworzą bezpośrednie ograniczenie otworu szyjnego. W kościach tych znajdują się wcięcia szyjne, które tworzą omawiany otwór. Wcięcia te są przedzielone wyrostkami śródszyjnymi. Przedłużeniem wyrostków śródszyjnych jest łącznotkankowa, rzadziej kostna przegroda otworu [2-4]. Ukształtowanie obramowań kostnych otworu szyjnego oraz dzielącej go przegrody wpływa na jego znaczną zmienność osobniczą $[2,7]$. Relacje topograficzne między przegrodą otworu a przechodzącymi przez niego tworami skłaniają do wyodrębnienia jego przedniej części, przez którą przechodzą nerwy, i tylnej, przez którą przechodzą tętnice oponowe, wodociąg ślimaka oraz kanał żylny składający się z zatoki esowatej, opuszki żyły szyjnej i żyły szyjnej wewnętrznej. Taki podział jest poprawny z radiologicznego punktu widzenia [11]. Skłaniał się również do niego w swoim pierwszym opracowaniu Rhoton [8].
Dokładne poznanie dopływów wspomnianego wyżej kanału żylnego sprawiło, że w otworze szyjnym zostały wskazane trzy przedziały anatomiczne - dwa żylne i jeden nerwowy [3]. Najbardziej z przodu znajduje się mniejszy z dwóch przedziałów żylnych, nazwany skalistym. Swoją nazwę bierze on od zatoki skalistej dolnej. Za przedziałem skalistym znajduje się przedział nerwowy. Najbardziej ku tyłowi usytuowany jest drugi, większy przedział żylny, nazwany esowatym. Jego zawartość, oddzielona od przedziału nerwowego przegrodą, odpowiada tradycyjnie rozumianej tylnej części otworu szyjnego. Zatoka skalista dolna może uchodzić zarówno do końcowego odcinka zatoki esowatej, do opuszki żyły szyjnej, jak i do początkowego odcinka żyły szyjnej wewnętrznej [2-4]. Ujście to może następować za pośrednictwem jednego, dużego przewodu żylnego lub kilku mniejszych [2]. Najczęściej układają się one do tyłu od nerwu językowo-gardłowego i do przodu od nerwu błędnego i dodatkowego [2,3,7]. Zdarza się jednak ich lokalizacja do tyłu od nerwu dodatkowego $[2,4,7]$ lub do przodu od nerwu językowo-gardłowego $[4,7]$. Poza zatoką skalistą dolną, kanał żylny przechodzący przez otwór szyjny ma cztery inne dopływy. Należą do nich splot żylny tętnicy kręgowej, żyła wypustowa kłykciowa tylna, splot żylny kanału nerwu podjęzykowego oraz żyła skalista dolna biegnąca pod podstawą czaszki, wzdłuż szczeliny skalisto-potylicznej [3]. Z zatoką skalistą dolną, która stanowi główny odpływ zatoki jamistej i splotu podstawnego, komunikuje się splot żylny tętnicy szyjnej wewnętrznej [3].

Patrząc od strony światła tylnego dołu czaszki na okolicę otworu szyjnego, wyścieloną oponą twardą, napotyka się w oponie dwa rozwory. Przez przedni, otoczony od przodu i góry fałdem, przechodzi nerw językowo-gardłowy, a przez tylny nerwy błędy i dodatkowy $[2,3]$. Chronologia topograficzna, polegająca na tym, że na przedniej powierzchni kanału żylnego przechodzącego przez otwór szyjny układają się z przodu nerw językowo-gardłowy, w środku nerw błędny, a z tyłu nerw dodatkowy, jest na ogół zachowana $[2,4]$. Zdarza się, że przedni przebieg nerwu językowo-gardłowego jest zaakcentowany przez oddzielenie go od pozostałych dodatkowa przegrodą kostną $[3,4,10]$. Ayeni i wsp. [2] zwracają uwagę, że zaburzenia topograficzne, jakie wynikają z obecności guzów otworu szyjnego i jego otoczenia, sprawiają, że szczególnie narażony na uszkodzenie jest nerw językowo-gardłowy.

Pierwsze próby chirurgicznego leczenia guzów otworu szyjnego podjęto w latach 40. [12] i 50. [13] ubiegłego stulecia i dotyczyły one przyzwojaków. Ten 
typ guzów, szczególnie trudnych do resekcji, prowokował kolejne pokolenia chirurgów do udoskonalania techniki operacyjnej otworu szyjnego i jego otoczenia. W latach 60. zaczęto stosować dostępy rozszerzone o penetrację pęczka naczyniowo-nerwowego szyi [14]. Dalszy postęp wiąże się z chirurgicznymi koncepcjami House'a [15,16], Glasscocka [17], Gardnera [18], Kempego [19] oraz Hildinga i Greenberga [20]. Koncepcje te są zawarte, usystematyzowane i udoskonalone w opisie dostępu podskroniowego typu A dokonanym przez Fisha [21-23]. Dostęp ten polega na uzyskaniu kontroli nad pęczkiem naczyniowo-nerwowym szyi, na amputacji przewodu słuchowego zewnętrznego i zawartości jamy bębenkowej, na repozycji przedniej nerwu twarzowego oraz na wyeksponowaniu odcinka skalistego tętnicy szyjnej wewnętrznej.

Dostęp podskroniowy typu A nazywany też bywa „zausznym przezskroniowym” [3], „przezskroniowo-podskroniowym” [24], „zausznym przezskroniowo-podskroniowym skrajnie bocznym” [25], „szyjno-przezsutkowym” [26], „połączonym podskroniowym i tylnojamowym” [27] czy też „podpotyliczno-przezlabiryntalnym bocznym” [28].

Koncepcja dostępu podskroniowego typu A polega na uzyskaniu wglądu do otworu szyjnego od strony górnej. W opinii George'a i wsp. [6] nawet doświadczonemu operatorowi, stosującemu ten dostęp, trudno jest uniknąć powikłań w postaci zaburzeń funkcji nerwu twarzowego, nie mówiąc o upośledzeniu słuchu. Autorzy ci zaproponowali dostęp do otworu szyjnego od strony tylnej. Opatrzyli go nazwą „okołokłykciowy”. Dostęp rozpoczyna identyfikacja pęczka naczyniowo-nerwowego szyi oraz dalszej części odcinka V3 tętnicy kręgowej. Następnie dochodzi do resekcji tylno-dolnej części wyrostka sutkowatego, wyrostka szyjnego kości potylicznej i części tylno-bocznej kłykcia potylicznego. Podobną do dostępu okołokłykciowego koncepcję docierania do otworu szyjnego opisał Fukushima [29]. Dostęp okołokłykciowy daje ograniczony dostęp do otworu szyjnego w porównaniu z dostępem podskroniowym typu A, ale jest od niego mniej inwazyjny. Zdaniem Schippera [30] poprawia on wgląd do przedziału nerwowego omawianego otworu. Dostęp ten jest przydatny w usuwaniu oponiaków tego otworu [5]. Inwazyjność dostępu zaproponowanego przez Fischa skłoniła liczną grupę autorów do stosowania tego dostępu w modyfikacjach ograniczających zakres penetracji, ale też zmniejszających ryzyko powikłań [26,28,31-37]. Samii i Tatagiba [28] uważają, że część guzów otworu żły szyjnej, zwłaszcza tych, które nie wrastają do światła jamy bębenkowej, nie wymaga mobilizacji nerwu twarzowego. Jackson i wsp. [32] wprawdzie mobilizują nerw twarzowy, ale tylko w odcinku sutkowym, podczas gdy Fisch [21-23] mobilizuje również odcinek bębenkowy. Do usuwania guzów otworu szyjnego stosowana też bywa mastoidektomia w technice zamkniętej, czyli bez otwierania przewodu słuchowego zewnętrznego lub w technice otwartej, czyli z otwieraniem tego przewodu $[25,33]$. W ograniczeniu dostępu do otworu żyły szyjnej jeszcze dalej poszli Farrior [31] oraz Maniglia i wsp. [34], którzy ograniczyli się do hipotympanotomii, czyli dostępu ograniczonego takimi strukturami, jak zatoka esowata, odcinek sutkowy nerwu twarzowego i kanał półkolisty tylny. Należy zaznaczyć, że Fisch [22] również posługuje się podanymi wyżej, ograniczonymi technikami, ale w guzach, które są zlokalizowane w jamie bębenkowej i wyrostku sutkowatym, czyli obszarach zastrzeżonych dla laryngologów.

$\mathrm{Z}$ przytoczonego przeglądu metod chirurgicznego leczenia guzów otworu szyjnego wynika, że autorzy niniejszej pracy, decydując się na przyjęcie określonej strategii chirurgicznej, mieli do dyspozycji z jednej strony radykalny i przez licznych autorów zawężany dostęp od strony górno-przedniej autorstwa Fisha [21-23], a drugiej strony mniej rozpowszechniony i mniej radykalny, ale niosący też mniejsze ryzyko powikłań, dostęp opracowany przez George’a [6]. Stało się to podstawą zaproponowania techniki łączącej te dwie metody z jednoczesnym wskazaniem trzech zakresów dostępu, zależnych od rozmiarów i lokalizacji usuwanego guza.

Większość autorów układa operowanego na wznak, skręcając głowę w stronę przeciwną do operowanej o kąt od $60^{\circ}$ do $90^{\circ}[22,25,28]$. Sporadycznie jest stosowana pozycja boczna również ze skręceniem głowy w stronę przeciwną do operowanej [38]. Ponieważ znaczne skręcenie głowy może upośledzić krążenie żylne, autorzy niniejszej pracy, podobnie jak Anand i Al-Mefty [39] układaja chorych na wznak z barkiem uniesionym po stronie operacji o około $45^{\circ}$, z rotacja głowy w stronę przeciwną do operacji tylko o $30^{\circ} \mathrm{i}$ z zapewnieniem sobie możliwości dalszej rotacji bocznej całego stołu operacyjnego w czasie operacji.

Początkowo Fisch [21,40] posługiwał się cięciem w kształcie litery „Y” Conleya, okalającym małżowinę uszną do przodu i od tyłu oraz schodzącym w dół, wzdłuż mięśnia mostkowo-obojczykowo-sutkowego. W późniejszych opracowaniach [22,23] opowiedział się za łukowatym cięciem zauszno-szyjnym, które daje lepszy wgląd operacyjny i łatwiej się goi. Fisch [22,23] 
górną część cięcia w okolicy skroniowej zawraca do góry i do tyłu, podczas gdy większość autorów wykorzystuje długi łuk rozpoczynający się w okolicy skroniowej, okalający małżowinę uszną od góry i tyłu i kończący się w połowie długości mięśnia mostkowo-obojczykowo-sutkowego [9,25,26,28,39,41]. George [6] swoje cięcie prowadzi wzdłuż mięśnia mostkowo-obojczykowo-sutkowego, ku górze nad wyrostek sutkowaty i w kierunku tylnym, nad okolicę podpotyliczną. Autor tej pracy posługuje się cięciem szyjno-zausznym, jednak z uwagi na planowany dostęp od tylno-dolnej części otworu szyjnego, przebiega ono około $5 \mathrm{~cm}$ do tyłu od nasady małżowiny usznej.

Odcięcie od wyrostka sutkowatego mięśni, dla których jest on przyczepem, zwłaszcza mostkowo-obojczykowo-sutkowego i dwubrzuścowego, jest czynnością opisywaną w większości opracowań [23,24,26,38,40-42]. Odpreparowanie mięśni okolicy podpotylicznej umożliwia zarówno identyfikację tętnicy kręgowej [25], jak i dostęp do tylno-dolnego ograniczenia otworu szyjnego [6].

Identyfikacja pęczka naczyniowo-nerwowego szyi pozwala na podwiązanie żyły szyjnej wewnętrznej oraz naczyń należących do tylnej grupy odgałęzień tętnicy szyjnej zewnętrznej, czyli tętnicy gardłowej wstępującej, tętnicy potylicznej i tętnicy usznej tylnej $[22,43]$.

Resekcja wyrostka rylcowatego wraz ze związanymi z nim mięśniami i ścięgnami oraz subluksacja żuchwy pozwala na prześledzenie przebiegu nerwów czaszkowych językowo-gardłowego, błędnego, dodatkowego i podjęzykowego oraz tętnicy szyjnej wewnętrznej w końcowej części odcinka szyjnego [36,43-46].

Fisch [47] podwiązuje zatokę esowatą w każdym przypadku penetracji guza do opuszki żyły szyjnej. Sekhar i wsp. [25] poprzedzają podwiązanie tej zatoki pomiarem panującego w niej ciśnienia po czasowym zamknięciu. Zdaniem tych autorów, zamknięcie zatoki esowatej jest możliwe, gdy po jej czasowym zamknięciu ciśnienie nie wzrasta więcej niż o 5 mm Hg. Sanna [36] i Schipper [30] zwracają uwagę, że podwiązanie zatoki esowatej może być zastąpione jej nacięciem i wypełnieniem surgicelem. Autorzy niniejszej pracy potwierdzają skuteczność takiego rozwiązania.

Technika resekcji struktur ucha środkowego oraz mobilizacji przedniej nerwu twarzowego została drobiazgowo opisana przez Fischa $[22,23,40]$ i zobrazowana w formie atlasu operacyjnego, który opracował Sanna [36].

W leczeniu operacyjnym guzów otworu szyjnego i jego otoczenia, jednym z największych wyzwań jest zachowanie funkcji nerwu twarzowego. Zdarza się nie stwierdzać niedowładu tego nerwu przed zabiegiem chirurgicznym, a rozrost guza do światła jamy bębenkowej zmusza do mobilizacji nerwu od zwoju kolanka do podziału w śliniance przyusznej i do jego przemieszczania do przodu, poza zakres działań operacyjnych. Panuje zgodność co do tego, że taki manewr, poprawnie wykonany, wywołuje u większości leczonych jedynie przejściowy niedowład nerwu twarzowego [22,23,32,36,38-41,47]. Zgodnie z założeniami, jakie uczynił Fisch $[22,23,40]$, mobilizacja przednia obejmuje odcinek sutkowy i bębenkowy nerwu twarzowego, czyli aż do zwoju kolanka. W niektórych przypadkach wystarczająca jest jedynie mobilizacja odcinka sutkowego. Jest ona wówczas określana jak mobilizacja krótka. Jeżeli ciągłość nerwu zostanie przerwana, bądź to z przyczyn jatrogennych, bądź z uwagi na nacieczenie nowotworowe, nerw powinien zostać zrekonstruowany. Wchodzi w grę albo przeszczep kablowy, albo zespolenie z nerwem podjęzykowym. W przypadku dostępu skalistego tylnego najkorzystniejsze jest wykonywanie przeszczepu nerwu usznego wielkiego. Z obserwacji Fischa i Mattoxa [22] wynika, że po zastosowaniu przeszczepu kablowego pozytywny rezultat uzyskuje się u $65 \%$ chorych, a po zespoleniu z nerwem podjęzykowym - u 50\%.

Dostęp skalisty dolny, zrealizowany we wszystkich trzech zakresach, pozwala na usunięcie większości guzów otworu szyjnego i jego otoczenia, również tych, które wnikają do kąta mostowo-móżdżkowego.

Istotnym osiągnięciem Fischa [22,40] jest opracowanie koncepcji jednoetapowego leczenia guzów otworu szyjnego, które rozrastają się wzdłuż tętnicy szyjnej wewnętrznej, w podstawie środkowego dołu czaszki. Koncepcja Fischa [22,40], którą nazwał, w zależności od rozległości guza, dostępem podskroniowym typu B lub $\mathrm{C}$, jest ujęciem w jeden ciąg działań chirurgicznych dostępu podskroniowego typu A w połączeniu z dostępem podskroniowym rozszerzonym [48] i dostępem skalistym całkowitym.

W przypadku, gdy guz otworu szyjnego rozrasta się w kierunku otworu potylicznego wielkiego, dostęp skalisty dolny może zostać połączony z dostępem przezkłykciowym częściowym [49].

Należy mieć nadzieję, że prawdziwy przełom w ograniczeniu inwazyjności chirurgicznego leczenia guzów otworu szyjnego i jego otoczenia zostanie dokonany z chwilą wprowadzenia endoskopowych metod tego leczenia [50]. 


\section{Oświadczenie}

Autorzy zgłaszają brak konfliktu interesów.

\section{Piśmiennictwo}

1. Al-Mefty O., Teixeira A. Complex tumors of the glomus jugulare: criteria, treatment, and outcome. J Neurosurg 2002; 97: 1356-1366.

2. Ayeni A., Ohata K., Tanaka K. i wsp. The microsurgical anatomy of the jugular foramen. J Neurosurg 1995; 83: 903-909.

3. Katsuta T., Rhoton A., Matsushima T. The jugular foramen: microsurgical anatomy and operative approaches. Neurosurgery 1997; 41: 149-202.

4. Lang J., Weigel M. Nerve-vessel relations in the region of the jugular foramen. Anat Clin 1983; 5: 41-56.

5. Arnautović K., Al-Mefty O. Primary meningiomas of the jugular fossa. J Neurosurg 2002; 97: 12-20.

6. George B., Lot G., Huy T. The juxtacondylar approach to the jugular foramen (without petrous bone drilling). Surg Neurol 1995; 44: 279-284.

7. Saleh E., Naguib M., Aristegui M. i wsp. Lower skull base: anatomic study with surgical implications. Ann Otol Rhinol Laryngol 1995; 104: 57-61.

8. Rhoton A., Buza R. Microsurgical anatomy of the jugular foramen. J Neurosurg 1975; 42: 541-550.

9. Tummala R., Coscarella E., Morcos J. Surgical anatomy of the jugular foramen. Operative Techn Neurosurg 2005; 8: 2-5.

10. Özveren F., Türe U., Özek M. i wsp. Anatomic landmarks of the glossopharyngeal nerve: a microsurgical anatomic study. Neurosurgery 2003; 52: 1400-1410.

11. Shapiro R. Compartmentation of the jugular foramen. J Neurosurg 1972; 36: 340-343.

12. Rosenwasser H. Carotid body tumor in the middle ear and mastoid. Arch Otolaryngol 1945; 2: 41-64.

13. Capps F. Glomus jugulare tumors of the middle ear. J Laryngol Otol 1952; 66: 302-314.

14. Shapiro M., Neues D. Technique for removal of glomus jugulare tumors. Arch Otolaryngol 1964; 79: 219-224.

15. House W., Glasscock III M. Glomus tympanicum tumors. Arch Otolaryngol 1968; 87: 550-554.

16. House W., Histelberger W. The transcochlear approach to the skull base. Arch Otolaryngol 1976; 102: 334-342.

17. Glasscock III M., Harris P., Newscome G. Glomus tumors: diagnosis and treatment. Laryngoscope 1974; 84: 2006-2032.

18. Gardner G., Cocke E., Robertson J. Chemodectomas of the glomus jugulare tumors. Laryngoscope 1977; 87: 665-688.

19. Kempe L., Vanderark G., Smith D. The neurosurgical treatment of glomus jugulare tumors. J Neurosurg 1971; 5: 9-64.

20. Hilding D., Greenberg A. Surgery for large glomus jugulare tumor. Arch Otolaryngol 1971; 93: 227-231.

21. Fisch U. Infratemporal fossa approach for extensive tumors of the temporal bone and base of the skull. W: Silverstein H. [red.]. Neurological surgery of the ear. Aesculapius, Birmingham 1977, ss. 34-53.
22. Fisch U., Mattox D. Microsurgery of the skull base. Georg Thieme Verlag, Stuttgart 1988.

23. Jenkins H., Fisch U. Glomus tumors of the temporal region. Arch Otolaryngol 1981; 107: 209-214.

24. Patel S., Sekhar L., Cass S. i wsp. Combined approaches for resection of extensive glomus jugulare tumors. J Neurosurg 1994; 80: 1026-1038.

25. Sekhar L., Kim S., Wright D. i wsp. Surgical treatment of jugular foramen lesions. W: Dickman C., Spetzler R., Sonntag V. [red.]. Surgery of the craniovertebral junction. Thieme, New York 1998, ss. 633- 658.

26. Samii M., Babu R., Tatagiba M. i wsp. Surgical treatment of jugular foramen schwannomas. J Neurosurg 1995; 82: 924-932.

27. Al-Mefty O., Fox J., Rifai A. i wsp. A combined infratemporal and posterior fossa approach for the removal of giant glomus tumors and chondrosarcomas. Surg Neurol 1987; 28: 423-431.

28. Samii M., Tatagiba M. Approaches to the jugular foramen. W: Dickman C., Spetzler R., Sonntag V. [red.]. Surgery of the craniovertebral junction. Thieme, New York 1998, ss. 621-632.

29. Fukushima T. Combined supra- and infra-parapetrosal approach for petroclivial lesion. W: Sekhar L., Janecka I. [red.]. Surgery of cranial base tumors. Raven Press, New York 1993, ss. 661-669.

30. Schipper J., Spetzger U., Tatagiba M. i wsp. Juxtacondylar approach in temporal paraganglioma surgery: when and why? Skull Base 2009; 19: 43-47.

31. Farrior J. Anterior hypotympanic approach for glomus tumor of the infratemporal fossa. Laryngoscope 1984; 94: 1016-1021.

32. Jackson G., Cueva R., Thedinger B. i wsp. Conservation surgery for glomus jugulare tumors: the value of early diagnosis. Laryngoscope 1990; 100: 1031-1036.

33. Jackson G., Cueva R., Thedinger B. i wsp. Cranial nerve preservation in lesions of the jugular fossa. Otolaryngol Head Neck Surg 1991; 105: 687-693.

34. Maniglia A., Sprecher R., Megerian C. i wsp. Inferior mastoidectomy-hypotympanic approach for surgical removal of glomus jugulare tumors: an anatomical and radiologic study emphasizing distances between critical structures. Laryngoscope 1992; 102:407-414.

35. Poe D., Jackson G., Glasscock M. i wsp. Long-term results after lateral cranial base surgery. Laryngoscope 1991; 101: 372-378.

36. Sanna M., Saleh E., Russo A. i wsp. Atlas of temporal bone and lateral skull base surgery. Georg Thieme Verlag, Stuttgart 1995.

37. Mazzoni A. The petro-occipital trans-sigmoid approach for lesions of the jugular foramen. Skull Base 2009; 19; 48-56.

38. Pellet W., Cannoni M., Pech A. The widened transcochlear approach to jugular foramen tumors. J Neurosurg 1988; 69: 887-894.

39. Anand V., Al-Mefty O. Surgical treatment of intracranial glomus tumors. W: Torrens M., Al-Mefty O., Kobayashi S. [red.]. Operative skull base surgery. Churchill Livingstone, New York 1997, ss. 295-312.

40. Fisch U., Pillsbury H., Infratemporal fossa approach to lesions in the temporal bone and base of the skull. Arch Otolaryngol 1979; 105: 99-107. 
41. Jackson G., Glasscock III M., Harris P. Glomus tumors. Arch Otolaryngol 1982; 108: 401-406.

42. Smith P., Backer R., Kletzker R. i wsp. Surgical management of transcranial hypoglossal schwannomas. Am J Otol 1995; 16: 451-456.

43. Coscarella E., Tummala R., Morcor J. Infratemporal fossa approaches to the jugular foramen. Operative Techn Neurosurg 2005; 8: 25-30.

44. Balagura S., Carter J., Gossett D. Surgical approach to the high subcranial internal carotid artery. Neurosurgery 1985; 16: 402-405.

45. Fisher D., Clagett P., Parker J. i wsp. Mandibular subluxation for high carotid exposure. J Vasc Surg 1984; 1:727-733.

46. Shaha A., Philips T., Scalea T. i wsp. Exposure of the internal carotid artery near the skull base: The posterolateral anatomic approach. J Vasc Surg 1988; 8: 618-622.

47. Suarez C., Sevilla M., Llorente J. Temporal paragangliomas. Eur Arch Otorhinolaryngol 2007; 264: 719-731.

48. Ładziński P., Maliszewski M., Kaspera W. i wsp. Dostęp podskroniowy rozszerzony do dołu podskroniowego i jego otoczenia - analiza techniki operacyjnej na podstawie symulacji na zwłokach. Neurol Neurochir Pol 2010; 44; 159-171.

49. Catalano P., Davis C. Variation and modifications of the infratemporal fossa approaches. Operative Techn Neurosurg 2005; 8: 31-34

50. Dallan I., Bignami M., Battaglia P. i wsp. Fully endoscopic transnasal approach to the jugular foramen: Anatomic study and clinical consideration. Neurosurgery 2010; 67 [ONS Suppl 1]: ons1-ons8. 